\title{
PENERAPAN MODEL PEMBELAJARAN NUMBERED HEAD TOGETHER UNTUK MENINGKATKAN HASIL BELAJAR SISWA PADA MATA PELAJARAN BAHASA INGGRIS DI SMAN 4 TEBO
}

\author{
RUMIATI NINGSIH \\ SMA Negeri 4 Kabupaten Tebo Provinsi Jambi \\ Email : rumiatiningsih9@gmail.com
}

\begin{abstract}
ABSTRAK
Penelitian ini bertujuan untuk menerapkan Model Pembelajaran Numbered Head Together (NHT) untuk meningkatkan hasil belajar siswa pada mata pelajaran Bahasa Inggris di kelas XII IPA 1 SMA Negeri 4 kabupaten Tebo tahun pelajaran 2019/2020. Penelitian ini merupakan Penelitian Tindakan Kelas (PTK) yang dilakukan dalam dua tahapan siklus. Siklus I terdiri dari dua kali pertemuan dan Siklus II terdiri dari dua kali pertemuan. Setiap siklus terdiri dari empat tahap yaitu perencanaan, pelaksanaan tindakan, pengamatan dan refleksi. Subjek dalam Penelitian ini adalah siswa kelas XII IPA 1 SMA Negeri 4 kabupaten Tebo yang berjumlah 34 siswa. Indikator keberhasilan pada Penelitian ini adalah apabila 75\% siswa dapat mencapai nilai Kriteria Ketuntasan Minimal (KKM) yang ditentukan oleh sekolah yaitu 75. Hasil Penelitian menunjukkan bahwa dengan penerapan Model Pembelajaran Numbered Head Together (NHT) di kelas XII IPA 1 dapat terjadi peningkatan ketuntasan prestasi belajar siswa meningkat pada siklus I dengan rata-rata sebesar 76 meningkat menjadi 80,58 pada siklus II. Presentase ketuntasan belajar juga meningkat dari siklus I sebesar 70,58\% meningkat menjadi 82,35\% pada siklus II.
\end{abstract}

Kata Kunci: media pembelajaran mind mapping, hasil belajar, bahasa inggris.

\section{PENDAHULUAN}

Di era globalisasi saat ini yang syarat akan persaingan yang ketat dan terbuka pemerintah harus mampu menyikapi dunia pendidikan secara tepat dan bijak. Pendidikan memang telah menjadi penopang dalam meningkatkan sumber daya manusia sehingga tidak kalah bersaing dengan sumber daya manusia di negara-negara lain. Kemajuan suatu negara sangat didukung dengan kualitas dari sumber daya manusia yang dimiliki untuk menciptakan sumber daya manusia yang mampu bersaing, maka SDM yang berkualitas di persiapkan melalui proses pendidikan (Istiarsono, 2016).

Tidak hanya guru saja yang memiliki peran penting dalam proses pembelajaran, minat pada diri siswa dimulai dari rasa senang terhadap pembelajaran, rasa senang inilah yang nantinya membuat siswa akan berkonsentrasi pada setiap materi yang dipelajari. Rasa senang akan membantu siswa merasa nyaman dan mendorong siswa untuk lebih berperan aktif dalam pembelajaran. Keaktifan siswa dalam proses pembelajaran juga menunjukkan bahwa siswa merasa memiliki ikatan dengan apa yang sedang dipelajari (Sani, 2013).

Penelitian Tindakan Kelas. PTK adalah salah satu solusi yang ditawarkan untuk mengatasi masalah pembelajaran di kelas. Dilihat dari kemanfaatan yang diperoleh dari hasil PTK, salah satu di antaranya adalah berupa perbaikan. Melalui Penelitian tindakan kelas masalah-masalah pendidikan dan pembelajaran dapat dikaji, ditingkatkan, dituntaskan sehingga proses pendidikan dan pembelajaran yang inovatif dan hasil belajar yang lebih baik dapat diwujudkan secara sistematis (Ar, 2014). SMA Negeri 4 Tebo telah menerapkan kurikulum 2013 yang salah satu mata pelajaran kelompok wajib adalah Bahasa Inggris dan juga pilihan pemitan ilmu- ilmu Bahasa dan budaya. Bahasa Inggris sebagai bahasa internasional yan digunakan untuk sarana interaksi sosial di seluruh penjuru dunia termasuk di Indonesia.

Bahasa merupakan sarana komunikasi baik secara lisan atau tertulis. Dalam kehidupan sehari-hari manusia saling berkomunikasi dan berinteraksi satu sama lain dengan menggunakan 
media bahasa. Dengan demikian, bahasa memiliki peran dan fungsi yang penting sehingga manusia dapat menyampaikan ide pemikiran dan melakukan kontak-kontak sosial dengan orang lain (Yudantoro, 2014). Dengan bahasa manusia dapat membuat pernyataan, memberi perintah, mengajukan permohonan, membuat pertanyaan, menyatakan komitmen, dan melakukan berbagai kegiatan maupun tugas-tugas lain yang tak terbatas jumlahnya. Untuk dapat menggunakan bahasa untuk beraneka macam tujuan dan fungsi dengan baik dan benar, diperlukan ketrampilan berbahasa yang memadai. Unsur bahasa yang digunakan untuk mengungkapkan ketrampilan berbahasa meliputi pola kalimat, kosa kata, lafal dan ejaan. Penguasaan bahasa dan unsur bahasa sangat penting untuk meningkatkan ketrampilan berbicara dalam bahasa Inggris (Bardiyono, 2017).

Dalam pembelajaran bahasa Inggris, ada empat keterampilan yang harus dipahami oleh siswa agar dapat dikatakan mampu berbahasa Inggris, yaitu: mendengar, berbicara, membaca dan menulis. Keterampilan berbicara merupakan salah satu dari keempat keterampilan dalam pembelajaran bahasa Inggris yang harus dikuasai oleh siswa, karena berbicara termasuk sebagai keterampilan yang sangat penting dalam kegiatan komunikasi yaitu kegiatan dengan mengucapkan kata demi kata menjadi sebuah kalimat yang berisi ungkapan, opini, saran, tujuan atau maksud yang lain, yang nantinya akan didengarkan dan dapat dijadikan alat komunikasi dengan orang lain (Syahputra, 2015). Dalam berbicara diperlukan proses untuk mendapatkan hasil akhir yang nantinya dapat mengantarkan ide ide ke siswa atau orang lain sehingga siswa atau orang lain dapat mengerti maksud dan tujuan yang dibicarakan. Terkadang siswa mengalami kesulitan dalam menemukan ide dan mengutarakan apa yang telah dipikirkan ke dalam bentuk kata yang menggunakan bahasa Inggris. Maka perlu adanya teknik pembelajaran yang dapat memicu siswa untuk lebih mudah menyampaikan pesan dalam berbahasa Inggris (Widodo, dkk, 2018).

Realitas di lapangan menunjukkan bahwa kegiatan pembelajaran bahasa Ingggis belum dilaksanakan secara makimal sehingga membutuhkan penerapan model pembelajaran yang efektif dan efisien agar dapt meningkatkan partisipasi siswa sekaligus meningkatkan kemapuan siswa. Selain itu, guru mata pelajaran Bahasa Inggris belum memanfaatkan media pembelajaran secara maksimal saat mengajar yang ditunjukkan dengan tanpa adanya media (PPT) powerpoint, alat-alat peraga yang lain, padahal media pembelajaran dapat menarik dan mengarahkan perhatian siswa untuk berkonsentrasi pada isi pelajaran yang berkaitan dengan makna yang ditampilkan dalam materi pelajaran Salah satunya dengan menerapkan model pembelajaran Numbered Head Together.

Model pembelajaran kooperatif tipe Numbered Head Together ini, hal yang ingin disampaikan adalah bagaimana siswa mampu menerima berbagai pendapat yang diterima dan disampaikan oleh orang atau kelompok lain, kemudian menganalisisnya bersama, sehingga memunculkan pendapat yang paling ideal, atau bahkan tidak mendapatkan pendapat yang paling ideal. Inilah sebenarnya esensi dari perbedaan pendapat. Selanjutnya, guru memberikan kesimpulan terhadap jalannya pembahasan materi tersebut (Rahmawati, dkk, 2014). NHT Merupakan model pembelajaran kooperatif yang dikembangkan oleh Spencer Kagan dimana model pembelajaran ini memberikan kesempatan siswa untuk saling membagikan ide-ide dan mempertimbangkan jawaban yang tepat. NHT dapat digunakan untuk mengecek pemahaman anak terhadap mata pelajaran dengan cara melibatkan lebih banyak Siswa menelaah materi yang tercakup sehingga dapat meningkatkan penguasaan akademik dan kemampuan berfikir kritis (Hadiyanti, 2012).

Shoimin (2014:108) mengemukakan model pembelajaran kooperatif tipe NHT merupakan suatu model pembelajaran berkelompok yang setiap anggota kelompoknya bertanggung jawab atas tugas kelompoknya, sehingga tidak ada pemisahan antara siswa yang satu dengan siswa yang lain dalam satu kelompok untuk saling memberi dan menerima antara satu dengan yang lainnya. Dalam model pembelajaran ini, setiap siswa dalam kelompok mewakili nomor yang berbeda-beda dan secara bersama-sama mendiskusikan soal yang diberikan guru. Kemudian guru memanggil nomor 
tertentu dan siswa dari setiap kelompok yang mewakili nomor tersebut mengemukakan hasil diskusi kelompoknya. Dengan adanya diskusi, para siswa tentunya saling mengkomunikasikan ide matematisnya dalam kelompok secara lisan. Hasil diskusi tersebut dituangkan secara tertulis dalam lembar jawaban kelompok. Selain itu, pada saat siswa melaporkan hasil diskusi kelompok, siswa yang nomornya dipanggil mengkomunikasikan ide matematisnya kepada guru dan siswa yang lain. Dengan demikian, model pembelajaran kooperatif tipe NHT menunjang aspek komunikasi siswa (Lagur, dkk, 2018).

Adapun tujuan pendidikan dapat dilihat dari keberhasilan proses belajar yang dapat diukur melalui hasil belajar. asil belajar adalah hasil yang diperoleh melalui sebuah kegiatan belajar mata pelajaran tertentu secara mandiri untuk mengetahui seberapa jauh tujuan pembelajaran telah tercapai (Chulsum, 2017). Lebih lanjut dinyatakan bahwa hasil belajar merupakan akibat dari proses belajar seseorang. Hasil belajar terkait dengan perubahan pada diri orang yang belajar. Bentuk perubahan sebagai hasil dari belajar berupa perubahan pengetahuan, pemahaman, sikap dan tingkah laku, keterampilan dan kecakapan. Perubahan dalam arti perubahan-perubahan yang disebabkan oleh pertumbuhan tidak dianggap sebagai hasil belajar. Perubahan sebagai hasil belajar bersifat relatif menetap dan memiliki potensi untuk dapat berkembang (Lestari, 2015). Demikian pula dikatakan bahwa Hasil belajar adalah kemampuan- kemampuan yang telah dimiliki oleh siswa setelah ia mengalami proses belajarnya. Dalam proses belajar mengajar guru melakukan tugasnya tidak hanya menyampaikan materi kepada siswa, tetapi ia juga dituntut untuk membantu keberhasilan dalam menyampaikan materi pelajaran yaitu dengan cara mengevaluasi hasil belajar mengajar (Firmansyah, 2015).

\section{METODE PENELITIAN}

Jenis Penelitian yang digunakan adalah jenis Penelitian tindakan kelas. Penelitian tindakan kelas adalah suatu rangkaian langkah yang terdiri atas empat tahap, yakni perencanaan, tindakan, pengamatan dan refleksi (Kunandar D.R: 2008:42). Penelitian ini dilaksanakan di SMA Negeri 4 Tebo yang terletak di Jalan Air panas Kelurahan Sungai Bengkal Kecamatan Tebo Ilir Kabupaten Tebo Provinsi Jambi. Adapun waktu Penelitian dilaksanakan pada bulan Agustus 2019 sampai dengan selesai, dengan tahapan sebagai berikut melihat keadaan sekolah, membuat proposal Penelitian, studi pustaka, penyusunan instrument, dan mengadakan Penelitian.

Subjek dari Penelitian ini yaitu kelas XII IPA 1 SMA Negeri 4 Tebo tahun ajaran 2019/2020 yang berjumlah 34 siswa. Guru memilih subjek XII IPA 1 SMA Negeri 4 Tebo, dikarenakan berdasarkan pengalaman Guru sebagai tenaga pengajar mengajar SMA Negeri 4 Tebo, pada umumnya pembelajaran diajarkan menggunakan metode ceramah dan tanya jawab. Kondisi demikian bertolak belakang dengan kurikulum 2013.

Prosedur penelitian terdiri dari, perencanaan, pelaksanaan, pengamatan, dan refleksi. Teknik pengumpulan data menggunakan dokumentasi dan tes. Penelitian ini menggunakan teknik analisis data deskriptif kuantitatif. Data yang diperoleh akan dianalisis dan dipersentase yaitu data kuantitatif dari prestasi belajar mata pelajaran Bahasa Inggris siswa kelas XII IPA 1. Hasil perolehan data ini akan dianalisis pada setiap siklus, agar dapat diketahui ada atau tidaknya peningkatan hasil belajar siswa dengan penerapan model pembelajaran numbered head together (NHT).

\section{HASIL DAN PEMBAHASAN}

Penelitian Tindakan Kelas ini dilaksanakan di SMA Negeri 4 Tebo Provinsi Jambi. Adapun objek penelitian adalah 34 orang siswa kelas XII MIPA 1 semester ganjil tahun pelajaran 2019/2020 dengan fokus materi Teks News Item. Sekolah tersebut dipilih sebagai tempat penelitian karena SMA Negeri 4 Tebo merupakan tempat bertugas peneliti sehingga diyakini peneliti dapat memahami kompleksitas masalah pembelajaran dengan baik. 


\section{Siklus I}

Siklus I dilaksanakan tanggal 1 Agustus 2019 dan tanggal 8 Agustus 2019 adapun Materi yang diajarkan pada siklus I yaitu Teks News Item mengenai Fungsi sosial memberi informasi terkini, Struktur teks meliputi judul (headlines), paragraf pembukaan (newsworthy), latar belakang kejadian, (background events), dan source, berupa rangkaian paragraf yang merinci isi paragraf pembuka dan kutipan. Penelitian yang telah dilakukan menghasilkan data yang diuraikan menjadi sebagai berikut:

Tahap Perencanaan, Pada tahap perencanaan, diadakan pembagian kelompok terlebih dahulu. Pembagian kelompok didasarkan atas tingkat kecerdasan siswa yang dilihat dari Nilai Penilaian ulangan harian pada Kompetensi dasar sebelumnya. Persiapan yang dilakukan meliputi: (1) Menyusun RPP pada kompetensi dasar membedakan fungsi sosial, struktur teks, dan unsur kebahasaan beberapa teks news item lisan dan tulis, (2) Struktur teks news judul (headlines), paragraf pembukaan (newsworthy), latar belakang kejadian, (background events), sumber (source) berupa rangkaian paragraf yang merinci isi paragraf pembuka dan kutipan, (3) Menyusun soal tentang pengertian fungsi sosial, struktur teks, dan unsur kebahasaan beberapa teks news, item lisan dan tulis, (4) tujuan fungsi sosial, struktur teks, dan unsur kebahasaan beberapa teks news, item lisan dan tulis, (5) Menyiapkan peralatan yang akan digunakan dalam pembelajaran antara lain kamera untuk dokumentasi, spidol (warna-warni), kertas asturo, number stick, speaker, nomor undian.

Tahap Tindakan, Pertemuan pertama siklus I Materi yang diajarkan fungsi sosial, struktur teks, dan unsur kebahasaan beberapa teks news, item lisan dan tulis. Tujuan pembelajaran yang ingin dicapai adalah siswa mampu menguasai materi Teks News dan dapat menjelaskan materi tersebut dengan baik.

Tahap Pengamatan, Prestasi hasil Belajar Bahasa Inggris pada siklus I diperoleh dari soal post test yang dilakukan pada pertemuan ke dua tanggal 8 Agustus 2019.

Tabel 1. Hasil Post Test Siklus I bahasa Inggris

\begin{tabular}{ccc} 
No & Keterangan & Post Test \\
1 & Nilai Tertinggi & 90 \\
2 & Nilai Terendah & 55 \\
3 & Rata-rata Nilai & 76 \\
\hline
\end{tabular}

Tabel 2. Siswa yang sudah dan belum mencapai KKM siklus I

\begin{tabular}{|c|c|c|c|c|}
\hline \multirow{3}{*}{ Keterangan } & $\begin{array}{l}\text { Jumlah } \\
\text { siswa }\end{array}$ & Presentas & \multirow{2}{*}{\multicolumn{2}{|c|}{ Presentase }} \\
\hline & \multicolumn{2}{|c|}{ Jumlah siswa } & & \\
\hline & $<75$ & $>75$ & $<75$ & $>75$ \\
\hline Pos Tes & 10 & 24 & $29,41 \%$ & 70,58 \\
\hline
\end{tabular}

Berdasarkan data yang disajikan Pada tabel 1. Hasil post test siklus I nilai yang diperoleh peserta didik tertinggi yakni mencapai 90 dan nilai terendah yang dicapai peserta didik adalah 55 orang dengan nilai rata-rata mencapai 76,47 dan pada tabel.2 Jumlah siswa yang belum mencapai ketuntasan sebanyak 10 orang dengan rata-rata nilai mencapai 29,41\% sedangkan peserta didik yang telah mencapai ketuntasan Maksimal (KKM) sebanyak 24 orang siswa dengan rata-rata ketuntasan baru mencapai 70,58 \%. Berdasarkan data di atas, hasil pembelajaran siklus I belum 
menunjukkan keberhasilan tindakan, karena tindakan ini dikatakan berhasil apabila ada peningkatan prestasi belajar siswa dengan minimal 75\% siswa mencapai KKM yang telah ditentukan oleh sekolah sebesar 75 .

Tahap Refleksi, Setelah dilaksanakan pembelajaran pada siklus I dengan model pembelajaran numbered head together ini belum menunjukkan hasil yang maksimal sehingga perlunya dilaksanakan tindakan selanjutnya agar lebih baik lagi. Guru melakukan refleksi tentang kekurangan-kekurangan pada siklus I, refleksi dilakukan dengan memperhatikan hasil observasi, hasil tes dan pengamatan selama proses pembelajaran berlangsung. Dari kegiatan refleksi dapat diketahui permasalahan atau kendala yang dihadapi serta kelebihan dari model pembelajaran numbered head together. Dengan adanya kendala dalam siklus I ini maka, akan dilakukan perbaikan pada siklus II agar dapat mencapai indikator keberhasilan dalam Penelitian ini.

\section{Siklus II}

Siklus II dilaksanakan hari Selasa tanggal 22 Agustus 2019. Materi yang diajarkan pada siklus II yaitu Materi yang diajarkan fungsi sosial, struktur teks, dan unsur kebahasaan beberapa teks news, item lisan dan tulis. Tujuan pembelajaran yang ingin dicapai adalah siswa mampu menguasai materi Teks News Item dan dapat menjelaskan materi tersebut dengan harapan agar peserta memcapai ketuntasan yang maksimal. Langkah-langkah pelaksanaan pada Siklus II adalah sebagai berikut:

Tahap Perencanaan, Secara teknis pelaksanaan pada siklus II sama dengan siklus I dengan memperhatikan hasil refleksi yang diperoleh pada siklus I, terutama pada aspek yang belum mencapai skor minimal yang ditentukan.

Tahap Pelaksanaan, Pertemuan ketiga siklus II dilaksanakan pada tanggal 22 Agustus 2019 pukul 07.00 WIB sampai dengan pukul 08.30 WIB. Materi yang diajarkan Teks News mengenai Fungsi sosial memberi informasi terkini, Struktur teks meliputi judul (headlines), paragraf pembukaan (newsworthy), latar belakang kejadian, (background events), sumber (source) berupa rangkaian paragraf yang merinci isi paragraf pembuka dan kutipan. Tujuan pembelajaran yang ingin dicapai adalah siswa mampu menguasai materi Teks News Item dan dapat menjelaskan materi tersebut dengan baik. dengan model pembelajaran Numbered Head Together (NHT).

Tahap Pengamatan, Prestasi hasil Belajar Bahasa Inggris pada siklus II diperoleh dari soal post test yang dilakukan pada pertemuan ke empat tanggal 29 Agustus 2019. Hasil Belajar Bahasa Inggris selama siklus II dapat dilihat di tabel 3.

Tabel 3. Hasil post test Siklus II

\begin{tabular}{crc}
\hline No & Keterangan & Post Test \\
1 & Nilai Tertinggi & 95 \\
2 & Nilai Terendah & 70 \\
3 & Rata-rata Nilai & 80,58 \\
\hline
\end{tabular}

Tabel 4. Siswa yang sudah dan belum mencapai KKM Siklus II

\begin{tabular}{|c|c|c|c|c|}
\hline \multirow{3}{*}{ Keterangan } & $\begin{array}{l}\text { Jumlah } \\
\text { siswa }\end{array}$ & resent & & \\
\hline & \multicolumn{2}{|c|}{ Jumlah siswa } & \multicolumn{2}{|c|}{ Presentase } \\
\hline & $<75$ & $>75$ & $<75$ & $>75$ \\
\hline Pos Tes & 6 & 28 & $17,64 \%$ & $82,35 \%$ \\
\hline
\end{tabular}


Berdasarkan data pada kedua tabel di atas dapat dilihat bahwa rata-rata nilai post test pada siklus II adalah 80,58. Hal ini menunjukkan bahwa terjadi peningkatan hasil belajar dengan menggunakan model Numbered Head Together (NHT). Pada saat dilaksanakan post test siswa yang mencapai KKM adalah 82,35\%. Berdasarkan data dari siklus I dan siklus II, hasil belajar siswa mengalami peningkatan.

Pembelajaran menggunakan model Numbered Head Together ini bisa dikatakan berhasil karena persentase hasil belajar siswa lebih dari $75 \%$ dengan persentase sebesar $82,35 \%$, sehingga pembelajaran menggunakan model Numbered Head Together ini dapat dikatakan berhasil dan Penelitian bisa dihentikan pada siklus II.

Tahap Refleksi, Hasil Penelitian siklus II menunjukkan adanya peningkatan hasil belajar siswa. Rencana perbaikan yang dilaksanakan pada siklus I dapat dilaksanakan dengan baik pada siklus II. Hal tersebut terlihat dari data observasi siklus I.

\section{Pembahasan}

Penelitian ini merupakan Penelitian tindakan kelas yang menerapkan model pembelajaran numbered head together (NHT) dengan tujuan untuk meningkatkan hasil belajar Bahasa Inggris siswa. Penelitian ini dilaksanakan dengan empat tahapan yaitu perencanaan, pelaksanaan tindakan, pengamatan dan refleksi. Penelitian ini berlangsung dengan lancar dan baik. Berdasarkan post test dapat diketahui adanya peningkatan hasil belajar. Pengukuran hasil belajar bertujuan untuk mengukur sejauh mana siswa telah menguasai materi yang telah diajarkan. Keberhasilan ini ditunjukkan berdasarkan nilai post test.

\section{Tabel 5. Peningkatan Hasil Belajar Bahasa Inggris Siswa kelas XII IPA 1 SMA Negeri 4}

\section{Tebo}

\begin{tabular}{|c|c|c|c|c|c|c|c|}
\hline \multirow{2}{*}{ Siklus } & \multirow{2}{*}{ Keterangan } & \multirow{2}{*}{$\begin{array}{c}\text { Nilai } \\
\text { Terendah }\end{array}$} & \multirow{2}{*}{$\begin{array}{l}\text { Nilai } \\
\text { tertinggi }\end{array}$} & \multicolumn{2}{|c|}{ Jumlah siswa } & \multicolumn{2}{|c|}{ Presentase } \\
\hline & & & & Tuntas & Tuntas & $<75$ & $>75$ \\
\hline I & Pos Test & 55 & 90 & 10 & 24 & $29,41 \%$ & $70,58 \%$ \\
\hline II & Pos Test & 70 & 95 & 6 & 28 & $17,64 \%$ & $82,35 \%$ \\
\hline
\end{tabular}

Berdasarkan data yang disajikan pada tabel 5, hasil belajar siswa pada post test siklus I, siswa yang mencapai KKM adalah 24 orang atau 70,58\%. Terjadinya peningkatan saat post test siklus II yaitu menjadi 28 orang dengan presentasi mencapai 82,14\%. Hasil belajar Bahasa Inggris telah mencapai keberhasilan yaitu dari siklus I sebanyak 24 siswa $(70,58 \%)$ menjadi sebanyak 28 siswa $(82,35 \%)$ pada siklus II. Penelitian ini membuktikan bahwa terjadinya peningkatan prestasi belajar siswa dengan menggunakan model pembelajaran Numbered Head Together (NHT).

Dalam melaksanakan Guru ini terdapat beberapa keterbatasan dalam penerapan model pembelajaran Numbered Head Together (NHT) di kelas XII IPA 1 SMA Negeri 4 Tebo. Keterbatasan tersebut disebabkan oleh Model pembelajaran Numbered Head Together (NHT) merupakan model yang belum pernah diterapkan oleh guru sehingga siswa masih belum paham dalam melaksanakan pembelajaran menggunakan model pembelajaran Numbered Head Together (NHT) pada siklus I, oleh karena itu diperlukan instruksi yang lebih jelas sehingga pelaksanaan pembelajaran menggunakan model pembelajaran Numbered Head Together (NHT) dapat berjalan dengan baik di siklus II. 


\section{KESIMPULAN}

Berdasarkan hasil Penelitian yang telah dilakukan dan pembahasan pada bab IV, maka dapat disimpulkan bahwa: Penerapan model pembelajaran Numbered Head Together (NHT) pada aspek kognitif. Hal ini dibuktikan dengan adanya peningkatan nilai dari siklus I dengan rata-rata sebesar 76 meningkat menjadi 80,58 pada siklus II. Presentase ketuntasan belajar juga meningkat dari siklus I sebesar $70,58 \%$ meningkat menjadi $82,35 \%$ pada siklus II. Ketuntasan pada hasil belajar kognitif kemampuan berpikir tingkat tinggi. Hal ini menunjukkan bahwa penerapan model pembelajaran Numbered Head Together (NHT) dapat meningkatkan hasil belajar siswa mata pelajaran Bahasa Inggris kelas XII IPA 1 SMA Negeri 4 Tebo pada aspek kognitif. Berdasarkan kesimpulan dalam penelitian ini, beberapa saran sebagai berikut: (1). Bagi Guru: Guru sebaiknnya menerapkan model pembelajaran numbered head together dengan media mind mapping pada kompetensi dasar teoritik yang lain sehingga dapat tercipta suasana pembelajaran yang efektif dan menyenangkan yang pada akhirnya dapat meningkatkan prestasi belajar Bahasa Inggris siswa. (2). Bagi Siswa: Siswa hendaknya mengikuti model pembelajaran Numbered Head Together (NHT) dengan sungguh-sungguh karena pembelajaran ini mempunyai banyak keungggulan diantaranya menumbuhkan rasa bertanggung jawab pada diri siswa bukan hanya dalam diri sendiri namun juga mampu bertanggung jawab terhadap kelompoknya.

\section{DAFTAR PUSTAKA}

Ar, H. E. S. (2014). Penelitian tindakan kelas.

Bardiyono, B. (2017). Upaya Peningkatan Keterampilan Berbicara Bahasa Inggris pada Pembelajaran Narrative melalui Drama Di Kelas XI IPA 4 Semester 1 SMA Negeri 1 Blora Tahun Pelajaran 2017/2018. JURNAL PEDAGOGY, 10 (4), 43-61.

Chulsum, U. (2017). Pengaruh Lingkungan Keluarga, Kedisiplinan Siswa, Dan Motivasi Belajar Terhadap Hasil Belajar Ekonomi Siswa Di SMA Negeri 7 Surabaya. Jurnal ekonomi pendidikan dan Kewirausahaan, 5(1), 5-20.

Fimansyah, D. (2015). Pengaruh Strategi pembelajaran dan minat belajar terhadap hasil belajar matematika. Judika (Jurnal Pendidikan UNSIKA), 3(1).

Hadiyanti, R. (2012). Keefektifan Pembelajaran Kooperatif Numbered Head Together Terhadap Kemampuan Pemahaman Konsep. Unnes Journal of Mathematics Education, 1(1).

Istiarsono, Z. (2016). Tantangan Pendidikan dalam Era Globalisasi: Kajian Teoretik. Jurnal Pendidikan dan Pembelajaran, 1(2).

Lagur, D. S., Makur, A. P., \& Ramda, A. H. (2018). Pengaruh Model Pembelajaran Kooperatif Tipe Numbered Head Together (NHT) terhadap Kemampuan Komunikasi Matematis. Mosharafa: Jurnal Pendidikan Matematika, 7(3), 357-368.

Lestari, I. (2015). Pengaruh waktu belajar dan minat belajar terhadap hasil belajar matematika. Formatif: Jurnal Ilmiah Pendidikan MIPA, 3(2).

Rahmawati, D., Nugroho, S. E., \& Putra, N. M. D. (2014). Penerapan model pembelajaran kooperatif tipe numbered head together berbasis eksperimen untuk meningkatkan keterampilan proses sains siswa SMP. UPEJ Unnes Physics Education Journal, 3(1).

Sani, R. A. (2013). Inovasi pembelajaran. Jakarta: Bumi Aksara.

Shoimin, A. (68). Model Pembelajaran Inovatif dalam Kurikulum 2013 (A.-R. MEDIA, Ed.).

Yudantoro, E. (2014). Pintar dan Juara Bahasa Inggris SMA. PandaMedia.

Widodo, K., Suharno, S., \& Suwandi, S. (2018). Peningkatan Kemampuan Berbicara Siswa Menggunakan Tehnik Role-Play Pada Materi Ucapan Memberi Selamat Pada Siswa Kelas 10 Mipa 7 Sma Negeri 6 Semarang Tahun Ajaran 2018/2019. Media Penelitian Pendidikan: Jurnal Penelitian dalam Bidang Pendidikan dan Pengajaran, 12(2), 146151. 